\title{
CLINICAL STUDY OF ACUTE MYOCARDIAL INFARCTION IN YOUNG ADULTS WITH REFERENCE TO SERUM LIPOPROTEIN, SERUM HOMOCYSTEINE AND HS-CRP
}

\section{Dr. Felin Ānn Francis*}

\author{
Assistant Professor (Dept. Of General Medicine), D Y Patil Hospital, Nerul, \\ Navi Mumbai. *Corresponding Author
}

ABSTRACT INTRODUCTION - Recently, the prevalence of acute myocardial infarction (AMI) has been increasing in the younger generation. With the advances in the field of medicine, elevated serum levels of various biomarkers like c-reactive protein (CRP), various lipoproteins and homocysteine have been identified to be related to AMI.

OBJECTIVE - To clinically diagnose acute myocardial infarction in young patients and correlate the levels of serum lipoprotein, serum homocysteine and serum hs-crp and to calculate the level of risk depending on their levels.

METHOD - A hospital based observational study in which 50 subjects were enrolled in the study as per the inclusion and exclusion criteria.

RESULTS - The results support the current global findings of the younger generation, especially the males, being affected by AMI (Acute Myocardial Infarction). Sedentary lifestyle and BMI > 25 can be considered as major risk factors leading to AMI. A considerable proportion of our AMI patients had significantly elevated levels of homocysteine, hs-CRP and lipoprotein A and low levels of HDL-C indicating their correlation with AMI.

\section{KEYWORDS : Acute Myocardial Infarction, Serum Lipoprotein, Serum Homocysteine, Serum Hs-CRP.}

\section{INTRODUCTION}

Acute myocardial infarction (AMI) is a leading cause of morbidity and mortality worldwide. MI (or heart attack) occurs when myocardial ischemia, a diminished blood supply to the heart, exceeds a critical threshold and overwhelms myocardial cellular repair mechanisms designed to maintain normal operating function and homeostasis [1]. Owing to major changes in the biomarkers available for diagnosis, criteria for AMI have been revised.

The current International Consensus definition states that the term 'AMI' should be used where there is evidence of myocardial necrosis in a clinical setting consistent with myocardial ischemia. $[2,3]$

AMI is the most severe manifestation of CAD, which causes more than 2.4 million deaths in USA,

More than 4 million deaths in Europe and northern Asia, and more than one-third of deaths in developed nations annually. $[4,5]$

The incidence of AMI in India is $64.37 \backslash 1000$ people $\mathrm{n}$ men aged 29-69 years. Even though $80 \%$ of CVD [coronary vascular disease] cases are observed in the developing countries, majority of the studies conducted till now were conducted in developed countries. $[6,7]$

Signs and symptoms are quite variable, ranging from mild dyspnoea to cardio-pulmonary arrest. [8]

In this condition we revascularize occluded coronaries.[9] Patient should be treated immediately with medical therapy to relieve symptoms and ensure clinical stability in initial term.[10] Medical therapy includes morphine sulphate, Nitroglycerine or sodium nitroprusside, diuretics and ACE inhibitors, in addition to standard antiaggregant and anticoagulation therapies.[11]

\section{Method}

The study was initiated after obtaining approval from the Institutional Ethics Committee of Dr. DY Patil University School of Medicine, Nerul, Navi Mumbai. Written informed consent was obtained from all the patients prior to enrolling them in the study.

Study design: This was a prospective observational study.

Study Site: This study was conducted in the Departments of
General Medicine and Cardiology at Dr. D.Y. Patil University School of Medicine, Nerul, Navi Mumbai.

Study Population: This study was conducted in patients attending the tertiary care centre with sudden/gradual onset of discomfort in the anterior chest wall and fulfilling the eligibility criteria of the study.

Study duration: The study was conducted over a period of 2 years.

Sample size: 50 patients were enrolled in the study

\section{Study Selection Criteria:}

- Inclusion Criteria: The patients satisfying ALL the following criteria were enrolled into the study:

1. All patients less than 40 years of age having AMI;

2. Patients of either gender (male/female):

3. Patients willing to give informed consent and abide by the study procedure.

- Exclusion Criteria: The patients fulfilling ANY of the following criteria were excluded from the study:

1. Patients with recent or ongoing infection, fever or chronic inflammatory disorders like rheumatoid arthritis, system lupus erythematosus etc. or any other conditions which could have affected hs-CRP levels.

2. Patients not willing to give informed consent;

3. Patients above 40 years of age.

All young patients coming to the tertiary care centre with sudden/gradual onset of discomfort in the anterior chest wall (pain/ heaviness/pressure/gas) were evaluated on the basis of sign \& symptoms, BP, pulse, ECG findings, and cardiac enzymes. If the findings were suggestive of MI, then the patients were evaluated further for serum lipoprotein, serum homocysteine \& hs-CRP levels.

\section{RESULTS}

\section{Serum Homocysteine}

Table 1: Serum homocysteine

\begin{tabular}{|c|c|c|c|}
\hline Sr. homocysteine $(\mu \mathrm{mol} / \mathrm{L})$ & No. & $\%$ & p-value \\
\hline$\geq 30$ (Significant) & 36 & 72 & \multirow{2}{*}{0.0013} \\
\hline$<30$ (Insignificant) & 14 & 28 & \\
\hline
\end{tabular}

${ }^{*}$ Calculated using sign \& binomial test. P-value $<0.05$ considered statistically significant 


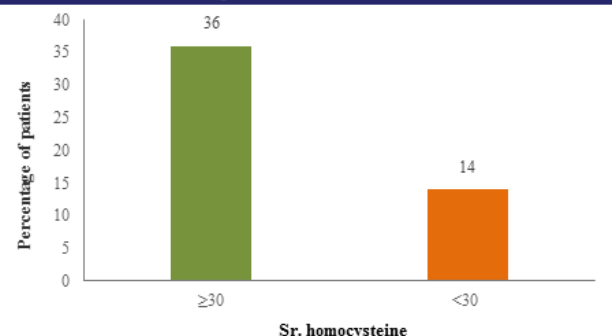

Figure 1: Serum homocysteine

In the current study, 36 (72\%) patients had significant serum homocysteine levels ( $\geq 30 \mu \mathrm{mol} / \mathrm{L}$ ) while $14(28 \%)$ patients had insignificant serum homocysteine levels $(<30 \mu \mathrm{mol} / \mathrm{L})$. Using the sign and binomial test, a statistically significant $(p=0.0013)$ proportion of the study patients had significantly higher serum homocysteine levels.

2.High-sensitive c-reactive protein (hs-CRP)

Table 2: hs-CRP

\begin{tabular}{|c|c|c|c|}
\hline hs-CRP (mg/L) & No. & $\%$ & p-value \\
\hline < l (Low risk) & 15 & 30 & \multirow{2}{*}{0.1611} \\
\cline { 1 - 3 } l -3 (Average risk) & 14 & 28 & \\
\cline { 1 - 3 }$>3$ (High risk) & 21 & 42 & \\
\hline
\end{tabular}

${ }^{*}$ Calculated using sign \& binomial test. P-value $<0.05$ considered statistically significant

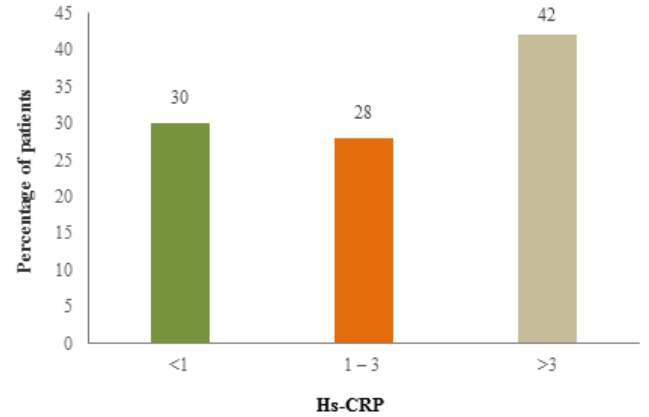

Figure 3: hs-CRP

In the current study, 21 (42\%) patients had hs-CRP levels $>3$ $\mathrm{mg} / \mathrm{L}$ i.e. considered high risk, 15 (30\%) patients had hs-CRP levels $<1 \mathrm{mg} / \mathrm{L}$ i.e. considered low risk while 14 (28\%) patients had hs-CRP levels ranging between 1 to $3 \mathrm{mg} / \mathrm{L}$ i.e. considered average risk. Using the sign and binomial test, no statistically significant $(p=0.1611)$ difference was observed between the proportion of patients having varied hs-CRP levels.

\section{Lipoprotein $\mathbf{A}$}

Table 3: Lipoprotein $\mathbf{A}$

\begin{tabular}{|c|c|c|c|}
\hline Lipoprotein A (mg/dL) & No. & $\%$ & p-value \\
\hline$>30$ (Significant) & 31 & 62 & 0.0595 \\
\hline$<30$ (Insignificant) & 19 & 38 & \\
\hline
\end{tabular}

*Calculated using sign \& binomial test. P-value <0.05 considered statistically significant

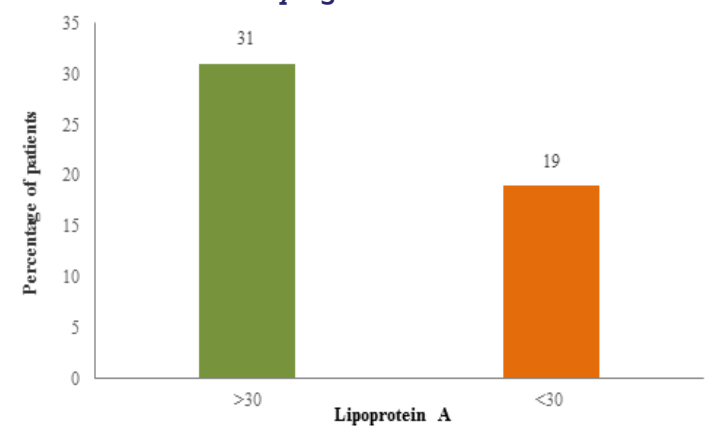

Figure 3: Lipoprotein $\bar{A}$
In our study, 31 (62\%) patients had significant lipoprotein $A$ (>30 mg/dL) while 19 (38\%) patients had insignificant lipoprotein $A$ ( $<30 \mathrm{mg} / \mathrm{dL}$ ). Using the sign and binomial test, a statistically significant $(p=0.0595)$ proportion of the study patients had significant levels of lipoprotein A.

\section{DISCUSSION}

Globally, acute $\mathrm{MI}$ is amongst the top causes of morbidity and mortality.[1] with the variance in signs and symptoms, diagnosis is challenging. [8] With the advancement in technology, various biomarkers have been identified that assist in the diagnosis of AMI.

C-reactive protein levels are found to be linked to diverse aspects of cardiovascular risk spectrum [12], and to the existence and degree of metabolic syndrome, subclinical atherosclerosis and its progression [13,14]. Hyper homocysteinemia has been associated with CVD [15-18].

Lipoproteins have been positively associated with CVD events and a stepwise increase in the risk of AMI and as a risk factor for CVD in patients with type 2 diabetes mellitus [19].

The mean age of patients presenting with AMI was recorded to be $35.10 \pm 4.65$ years.

A statistically significant proportion (80\%) were males.

Medical history of hypertension as present in 18(36\%) patients while Diabetes Mellitus was noted in 8(16\%).

Symptomatology- 92\% patients had chest pain, $86 \%$ had sweating, $32 \%$ had nausea and vomiting, $10 \%$ had breathlessness, $8 \%$ had palpitations \& $4 \%$ had diarrhoea.

The mean BMI of our study population was $26.11 \pm 4.97 \mathrm{~kg} / \mathrm{m} 2$.

Addictions reported amongst our study patients included smoking (30\%), alcohol (28\%) and tobacco use (4\%).

$56 \%$ patients were diagnosed with anterior wall MI, $8 \%$ with inferior wall MI with Right Ventricular MI, 28\% with Inferior Wall MI without Right Ventricular MI, $\%$ with Lateral Wall MI, and $6 \%$ with Posterior Inferior Wall MI.

Mean serum Homocysteine levels was $38.17 \pm 14.73$ micro $\mathrm{mol} / \mathrm{L}$. Mean hs-crp level was $3.86 \pm 3.63 \mathrm{mg} / \mathrm{L}$ with majority (42\%) patients having a high-risk level ( $>3 \mathrm{mg} / \mathrm{L}$ ).

Mean Apo Al level was $79.66 \pm 30.24$ mg/dl, with a statistically significant proportion of patients having levels between 55$140 \mathrm{mg} / \mathrm{dl}$.

The mean Apo Al/Apo B was $0.94 \pm 0,48$, a statistically significant proportion of patients having this ratio between 0.3 and 1 .

The mean total cholesterol level was $133.74 \pm 50.52 \mathrm{mg} / \mathrm{dL}$ with a statistically significant proportion of patients having levels $<125 \mathrm{mg} / \mathrm{dL}$.

The mean serum triglycerides level was $144.10 \pm 63.94 \mathrm{mg} / \mathrm{dL}$, with a majority (60\%) having normal (<150 mg/dL) serum triglyceride levels.

The mean HDL-C level was $36.54 \pm 9.21 \mathrm{mg} / \mathrm{dL}$, with $62 \%$ having HDL-C $<40 \mathrm{mg} / \mathrm{dL}$.

The mean LDL-C level was $92.22 \pm 51.00 \mathrm{mg} / \mathrm{dL}$, with a majority (54\%) having optimal ( $<85 \mathrm{mg} / \mathrm{dL}$ ) levels. The mean 1 ipoprotein $A$ was $39.06 \pm 23.21 \mathrm{mg} / \mathrm{dL}$, a statistically significant proportion of patients had significant levels ( $>30$ $\mathrm{mg} / \mathrm{dL}$ ) of lipoprotein $\mathrm{A}$. A positive correlation between 
diagnosis (i.e. anterior wall MI or inferior wall MI),

Apo Al (0.1734), Apo B (0.0419) and lipoprotein A (0.1386) was observed.

A negative correlation between diagnosis and serum homocysteine (-0.0708), hs-CRP (-0.2925), Apo-B/Apo Al ratio ($0.0290)$, total cholesterol $(-0.3408)$, serum triglycerides ($0.0130)$, HDL-C (-0.0015) and LDL-C (-0.1892) was observed.

\section{CONCLUSION}

- Acute Myocardial Infarction was diagnosed in young patients based on symptoms, ECG finding, cardiac screen.

- Majority were males, Should be overweight.

- A considerable proportion of our Acute myocardial Infarction patients have significantly elevated levels of homocysteine, hs-crp \& lipoprotein A indication their correlation with AMI.

\section{REFERENCES}

1. National Heart, Lung, and Blood Institute (NHLBI) [Internet]. National Institutes (NIH) June 2017].

Available from:

https://www.nih.gov/about-nih/what-we-do/nih-almanac/national-heartlung-blood-institute-nhlbi

2. Hamm CW, Bassand JP, Agewall S, Bax J, Boersma E, Bueno H, et al. Ese Guidelines for the management of acute coronary syndromes in patients presenting without persistent ST-segment elevation. Eur Heart J. 201 1: 32(23):2 999-3054.

3. Steg PH, James SK, Atar D, Badano LP, Lundgvist CB, Borger MA, et al. ESC Guidelines for the management of acute myocardial infarction in patients presenting with ST-segment elevation: The Task Force on the management of ST-segment elevation acute myocardial infarction of the European Society of Cardiology (ESC). Eur Heart J. 2012; 33(20):2569-619.

4. Nichols M, Townsend N, Scarborough P, Rayner M. Cardiovascular disease in Europe 2014: epidemiological update. Eur HeartJ. 2014: ehu299.

5. Yeh RW, Sidney S, Chandra M, Sorel M, Selby JV, Go AS. Population trends in the incidence and outcomes of acute myocardial infarction. N Engl J Med. 2010;362(23):2155-65

6. Reed G, Rosi J, Cannon C. Acute myocardial infarction. Lecture presented at: 2016; Department of Cardiovascular Medicine, Cleveland Clinic, Cleveland, OH, USA

7. Rao V, Rao P, Carvalho N. Risk factors for acute myocardial infarction in coastal region of India: A case-control study. Heart India. 2014; 2(3):70.

8. Brunner MP, Menon V. Cardiogenic shock complicating acute myocardial infarction. In: Griffin BP, Callahan TD, Menon V eds. Manual of cardiovascular medicine. 4th ed Philadelphia: Wolters Kluwer Health; 2013,

9. Jain SK, Larsen TR, DardaS, Saba S, David S. A forgotten devil; Rupture of mitral valve papillary muscle. Am J Case Rep. 2013, 14:38.

10. Magnoni M, Coli S, La Canna G, Meloni C, Cianflone D, Maseri A. Reduction of mitral valve regurgitation caused by acute papillary muscle ischemia. Nat Clin Pract Cardiovasc Med. 2007 Jan 1:4(1):51-4

11. Figueras J, Pena C, Soler-Soler J. Thirty-day prognosis of patients with acute pulmonary oedema complicating acute coronary syndromes. Heart. $2005 \mathrm{Jul}$ 1:91(7):889-93.

12. Hak AE, Bak AA, Lindemans J, Planellas J, Bennink HJ, Hofman A, et al. The effect of hormone replacement therapy on serum homocysteine levels in perimenopausal women: a randomized controlled trial. Atherosclerosis. 2001;158(2):437-43.

13. Ridker PM. Clinical application of C-reactive protein for cardiovascular disease detection and prevention. Circulation. 2003;107(3):363-9

14. Timpson NJ, Lawlor DA, Harbord RM, Gaunt TR, Day IN, Palmer LJ, et al. Creactive protein and its role in metabolic syndrome: mendelian randomisation study. Lancet. 2005;366(9501):1954-9.

15. Humphrey LL, Fu R, Buckley DI, Freeman M, Helfand M. Periodontal disease and coronary heart disease incidence: a systematic review and metaanalysis. J Gen Intern Med. 2008:23(12):2079.

16. Vizzardi E, Bonadei I, Zanini G, Frattini S, Claudia C, Raddino R, et al. Homocysteine and heart failure: an overview. Recent Pat Cardiovasc Drug Discov. 2009;4(1):15-21

17. Oudi ME, Aouni Z, Mazigh C, Khochkar R, Gazoueni E, Haouela H, et al. Homocysteine and markers of inflammation in acute coronary syndrome. Exp Clin Cardiol. 2010;15(2): e25.

18. Agoston-Coldea L, Mocan T, Gatfosse M, Lupu S, Dumitrascu DL. Plasma homocysteine and the severity of heart failure in patients with previous myocardial infarction. Cardiol J. 2011;18(1):55-62.

19. Kumakura $H$, Fujita $K$, Kanai $H$, Araki $Y$, Hojo $Y$ Kasama $S$, et al. Highsensitivity C-reactive protein, lipoprotein (a) and homocysteine are risk factors for coronary artery disease in Japanese patients with peripheral arterial disease. J Atheroscler Thromb 2015:22(4);344-54. 